\title{
Financial Closing Time And Cost Of Equity: The Role Of Senior Information Systems Executives
}

Mingjun Zhou, DePaul University, USA

Miguel Aguirre-Urreta, DePaul University, USA

\begin{abstract}
Financial closing time is the time lag between a firm's fiscal year end and earnings announcement. In this study, we first find an association between longer financial closing time and higher implied cost of equity. Improving financial closing time can help firms raise equity capital more efficiently. We posit that senior information executives can help improve firms' IT capabilities and reduce financial closing time. The empirical result suggests that firms having senior information executives (as measured by executive compensation) can reduce financial closing time for more than four days. We contribute by showing that senior IS executives are important for a public company to satisfy investors' information needs in the fast and competitive modern capital markets.
\end{abstract}

Keywords: Financial Closing Time; Implied Cost of Equity; IT capabilities; Senior IS Executives

\section{INTRODUCTION}

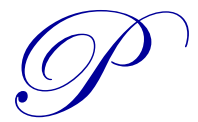

ublic firms differ in the length of time that is needed to report financial results from the last operating cycle, which is known as the reporting time lag or financial closing time. We test the effect of financial closing time on firm valuation and find that longer financial closing time is associated with higher cost of equity. Given the importance of financial closing time in firm valuation, we conjecture that the closing time is affected by the reporting capabilities of firms' accounting information systems, and having senior information systems (IS) executives may help improve the reporting capabilities, resulting in shorter closing time. We use executive compensation data to measure the power of firms' IS executives and find an association between shorter financial closing time and senior IS executives. We contribute to the stream of literature on the importance of information systems to reduce reporting time lag (Brazel and Dang, 2008) and on the role of senior information executives on firms' IT capabilities (Khallf and Skantz, 2007; Wang and Alam, 2007). Our research suggests that, on average, firms with senior IS executives are faster in their financial closing time by more than four days. Moreover, the presence of senior IS executives is associated with a lower cost of equity.

The rest of this paper is organized as follows. First, we develop the conceptual background for our study by reviewing the literature on the incentives faced by managers to report earnings information on a timely basis and the effect of financial closing time on cost of equity capital. Second, we describe the role of senior information executives in improving information system functions. We then describe the empirical models and discuss our regression-based results.

\section{BACKGROUND AND HYPOTHESES DEVELOPMENT}

\section{Firms' Reporting Behaviors}

Prior literature has largely assumed that the timing of financial information disclosures is directly under the control of management. Lee et al (2008) and Leventis and Weetman (2004) divide the time between fiscal year end 
and the earnings announcement date (their Total Report Lag, or TRL) into two different periods - the Audit Report Lag (ARL) and the Discretionary Report Lag (DRL). ARL is the time between the end of the fiscal year and the date of the signing of the auditor's report and DRL is the time between signing of the auditor's report and the date of earnings release. Under this conceptual framework, earnings are considered "ready for release" when an independent audit has been completed. Any delays between this and the actual earnings release date are discretionary time taken by managers with information that is already available to them privately.

However, companies are as likely to release earnings before the signing of the audit report as after that date (Lee et al 2008); thus, DRL can, at times, be negative. In Lee et al's (2008) sample of publicly listed companies that filed with the SEC from 2000 to 2004, over $43 \%$ of them released earnings before the date of the audit report. Since audit reports are not publicly available at the time of their signing, we take the earnings release date as the most significant date at which annual financial information is made publicly available. This is consistent with other work in this area (Chambers and Penman, 1984; Brazel and Dang, 2008; Landsman et al, 2011). The current underlying assumption in the literature is that managers can exercise discretion about the timing of their public release of earnings information and that firms having to report unfavorable news tend to delay earnings announcements. Empirical support for this finding is provided by Givoly and Palmon (1982), Chambers and Penman (1984), and Leventis and Weetman (2004).

Extant research has also shown that managers with results below expectations; that is, negative "earnings surprises" (Brazel and Dang, 2008), tend to delay making those public. For example, managers may choose to delay release of bad news until the release of industry-wide news in order for their specific bad news to be gradually impounded into stock prices (Haw et al, 2000). Managers may also delay with the hope that, in the interim, more positive news will arise that will offset the information content of the bad news they were holding onto (Haw et al, 2000; Kasznik and Lev, 1995). Finally, managers may hold back the release of bad news in order to complete extant projects and contracts in a more favorable light, or to attempt manipulation of negative results (Givoly and Palmon, 1982). In summary, these findings suggest that the timing of the release of earnings information is under the discretion of managers, and those with negative or unfavorable information may be tempted to delay those announcements.

\section{Financial Closing Time, Information Risk and Cost of Equity Capital}

Financial economics theory suggests that increased information asymmetry between managers and shareholders increases monitoring costs and/or the costly use of external debt financing (Myers and Majluf, 1984). Barry and Brown $(1985,1986)$ and Merton (1987) model the premium that investors demand for bearing information risks in the presence of asymmetries and reach a similar conclusion. The information asymmetry (or "lemons" problem) arises from the existence of different information sets between managers and investors, coupled with the presence of conflicting incentives. Due to the lack of accurate information, investors will rationally undervalue some good investments and overvalue some poor ones, relative to valuation information that is privately available to management (Healy and Palepu, 2001). There are a number of possible solutions to this problem. For example, optimal contracts could be written that provide incentives for full disclosure of private information or regulations could require the same level of disclosure. The existence of information intermediaries, such as rating agencies and financial analysts, is due, in part, to their ability to engage in costly searches geared toward uncovering private information.

Capital market participants may make additional demands that managers take action to minimize the existence of information asymmetries through stock valuations and price and volume reactions to specific events. For instance, timely financial disclosure contributes to the efficient functioning of stock markets so that rumors and information leaks will not be useful for market participants. Timely reporting also helps mitigate the negative effects associated with moral hazard and adverse selection that occur when one party is more informed about the true underlying value of a tradable asset (Leventis and Weetman, 2004). All else being equal, companies are expected to report information as timely as possible to avoid adverse selection (Grossman, 1981). At the same time, favorable news is met with better reactions and is likely to have attached to it a more positive reward for the discloser, which leads to firms with "good news" also wanting to release them as early as possible. Verrechia (1990) shows that a manager's incentives to disclose information are an increasing function of the favorableness of the information as 
well as a decreasing function of the proprietary costs (such as loss of competitive benefits resulting from other parties acting on the disclosed information) attached to the information under consideration.

Although investors cannot interpret delayed news as necessarily negative - they could be positive or neutral with high proprietary costs attached to them - investors still want to protect themselves by assuming a negative outcome when facing delayed news release. As a result, management is better off by releasing the information in a timely manner (Leventis and Weetman, 2004). The often-cited work of Diamond (1985) shows an overall welfare improvement from improved disclosure. Timely reporting and disclosure also lessen the need for information intermediaries (e.g., financial analysts, rating agencies) to undertake costly searches. In essence, managers are in a better position to reduce information asymmetries at lower costs, making both the principal and agent better off. For example, Givoly and Palmon (1982) show that there is a deterioration of the information content of late financial reports in terms of reduced price adjustments to the late releases. They attribute this deterioration to the inefficient and costly dissemination of information through alternative sources other than public earnings announcements. To summarize, the information risk inherent within reporting time lag leads us to expect that firms with longer financial closing time will incur a higher level of cost of equity capital.

H1: Firms with longer financial closing time have higher cost of capital, ceteris paribus.

\section{The Effects of Information Systems on Financial Reporting Time}

Although some managers, who learn about below-expectation earnings, may choose to delay announcing the results, others who want to make earnings announcements earlier cannot do so prior to its actual generation by the reporting systems. We posit that the minimum time required to produce internal earnings reports is not under immediate management discretion, but rather it is a function of existing financial transaction processing and reporting systems. Thus, the time lag, or the financial closing time between the end of the fiscal year and the generation of earnings report that could potentially be released to the public, is a function of the quality and sophistication of the existing reporting systems. Firms that release earnings late either have inefficient information systems, engage in strategic delays due to the negative content of the earnings release, or some combination of both. Early releasers, on the other hand, must have efficient and effective systems that enable them to make earnings reports available sooner rather than later.

The empirical evidence documented in Brazel and Dang (2008) supports this argument. They find that the number of days between fiscal year end and earnings release date decreases for good news (positive earnings surprise) firms, but only after implementation of an ERP system. Given that "earnings surprises" are, by definition, unexpected and random, the cross-sectional and time-series differences in the financial closing time across firms will be indicative of underlying differences in the quality and sophistication of information systems. To summarize, early earnings announcers should have efficient reporting systems that allow them to close the books faster. A shorter financial closing time should, in turn, mitigate the information risk and higher cost of equity that are associated with reporting time lag.

\section{The Role of Senior Executives in the Information System Functions}

The consensus in the literature indicates that the role of senior IS people in an organization is important. Grover et al (1993) find that chief information officers act as monitors and spokespersons to help the interaction between the Information Systems and accounting functions of firms. Ein-Dor and Segev (1981) show that senior executives in the information systems functions are relevant to the effectiveness of firms' management information systems. Rockart et al (1982) suggest that senior IS executives will not simply take the custodian and data processing function, but also, and more importantly, act as the corporate officers who truly understand the interconnection between the information flow and the business.

The upper echelon theory in management research argues that top executives are important determinants of firms' competitive advantage (e.g. Hambrick and Mason, 1984). As ERP systems become more prevalent since the mid-1990s, an increasing number of firms need managerial talents in their IS functions. The resource-based view in Mata et al (1995) suggests that firms' success depends on having access to unique resources and the ability to 
manage these resources. Senior IS executives reflect the human resource that makes the development of superior IT capability possible. For example, Mata et al (1995) consider managerial IT skills and senior IS executives to be a major source of firms' competitive advantage by enabling firms to deploy IT investments and integrate IT into existing business processes.

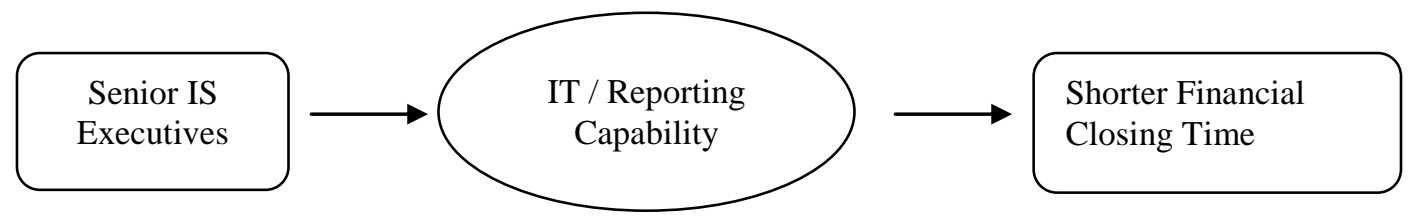

Figure 1: The Effect of Senior IS Executives on Financial Closing Time

Figure 1 illustrates the development of the hypothesis between senior IS executives and financial closing time. Because managers cannot release earnings information before its actual generation, senior IS executives can help by integrating technology into the business cycles to collect and summarize real-time data from firms' operating activities. The resulting IT capabilities improve the gathering of information for decision-making and lead to shorter financial closing time. Based on the resource-based view, senior IS executives are valuable strategic resources that are heterogeneously distributed across competing firms and difficult to acquire. Thus, we use executive compensation data as a proxy for the strategic importance of IS executives and test the association between senior IS executives and financial closing time.

H2: Senior Information Executives help reduce financial closing time.

\section{EMPIRICAL RESULTS}

\section{Implied Cost of Equity Capital}

Various approaches exist in the accounting and finance literature on the measurement of cost of capital, or investors' required returns on their equity investments. Prior work mostly uses ex-post realized stock returns as a measure of investors' required returns, but this measure is not theoretically sound and empirically satisfying in many aspects. In theory, realized returns observed ex-post tend to reflect the expectations of minority investors under heterogeneous expectations and short-selling constraints (Miller, 1977). Empirically, Fama and French (1997) conclude that cost-of-capital measures based on realized returns are imprecise and noisy at best. Elton (1999, p.1199) also argues that "realized returns are very poor measures of expected returns."

As a remedy, recent research in accounting and finance has proposed different methods to estimate investors' ex ante required return or implied cost of equity. Major estimation methods for this ex-ante measure of cost of capital have been developed by Gebhardt, Lee and Swaminathan (2001, hereafter GLS), Claus and Thomas (2001, hereafter CT), and Gode and Mohanram (2003, hereafter GM). Despite the use of different methods of estimation, the implied cost of equity is essentially the required discount rate or internal rate of return that equates an asset's market value or stock price to the present value of all expected future dividends. However, market expectations for future dividends are not easily observable. Thus, this stream of research uses analysts' earnings forecast as the baseline for market expectations of earnings and dividends. For example, the GLS measure of implied cost of equity capital is modeled with the following equation:

$$
P_{t}=B_{t}+\sum_{t=1}^{11} \frac{F R O E_{t+1}-r_{g l s}}{\left(1+r_{g l s}\right)} \cdot B_{t+i-1}+\frac{F R O E_{t+12}-r_{g l s}}{\left(1+r_{g l s}\right)^{11}} \cdot B_{t+11}
$$

$r_{g l s}$ is the empirical measure of the cost of equity capital, FROE is the forecasted return on equity. For year $t$ from one to three, FROE is the future return on equity estimate based on the assumption of future book value as $B_{t+1}=$ $B_{t}+k * F E P S_{t+1}$, where $F E P S_{t+1}$ is the mean of the one-year-ahead analyst earnings per share forecast in the Institutional Brokerage Estimate System (I/B/E/S) summary data; and $k$ is the dividend payout ratio. For $t$ beyond three, FROE is obtained through linear interpolation to median return on equity based on Fama and French's (1997) 
48 industries. The cost of capital estimate is the numerical value obtained through an iterative computation that minimizes the difference between price calculated from equation (2) and the actual market price at time $t$.

Different from the GLS approach, the Claus-Thomas (CT) measure deploy the concept of "abnormal earnings" in constructing their implied cost of equity measure:

$$
P_{t}=B_{t}+\frac{A E_{t+1}}{\left(1+r_{c t}\right)}+\frac{A E_{t+2}}{\left(1+r_{c t}\right)^{2}}+\ldots .+\frac{A E_{t+5}}{\left(1+r_{c t}\right)^{5}}+\frac{A E_{t+5}\left(1+g_{a e}\right)}{\left(r_{c t}-g_{a e}\right)\left(1+r_{c t}\right)^{5}}
$$

where $A E_{t}$ is the abnormal earnings for year $t$, and equal to $F E P S_{t}-r_{c t} * B_{t-1} ; F E P S_{t}$ is the mean $\mathrm{I} / \mathrm{B} / \mathrm{E} / \mathrm{S}$ analyst forecasted earnings ranging from years $t+1$ to $t+5$. When $\mathrm{I} / \mathrm{B} / \mathrm{E} / \mathrm{S}$ does not provide an earnings forecast for year $t+3$, $t+4$ or $t+5$, the available forecast for the preceding year is multiplied by one plus the consensus long-term growth rate in $\mathrm{I} / \mathrm{B} / \mathrm{E} / \mathrm{S}$ to arrive at an estimate for the relative time horizon. The estimated book value in the future is arrived in a way similar to that in GLS, but the dividend payout ratio of each period is set to be at a fixed 50 percent of the forecasted earnings of the corresponding period. $g_{a}$ is the growth rate of abnormal earnings beyond year $t+5$ and is set to be the yield on 10-year U.S. Treasury bonds minus $3 \%$ in the CT measure.

Different from the GLS and the CT approach, the GM measure does not require a computationally iterative solution for the positive root of a polynomial equation, but rather employs the following model:

$$
r_{e}=A+\sqrt{A^{2}+\left(\frac{F E P S_{t+1}}{P_{t}}\right)\left(g_{2}-r_{f}-0.03\right)}
$$

where $A=\frac{1}{2}\left(\left(r_{f}-0.03\right)+D P S_{t+1} / P_{t}\right) . \quad r_{f}$ is the yield of 10-year constant-maturity treasury bond and $g_{2}$ is the $\mathrm{I} / \mathrm{B} / \mathrm{E} / \mathrm{S}$ consensus long-term growth rate. $D P S_{t+1}$ is estimated as the forecasted earnings $\left(F E P S_{t+1}\right)$ times dividend payout ratio $k$.

\section{Sample and Regression Results}

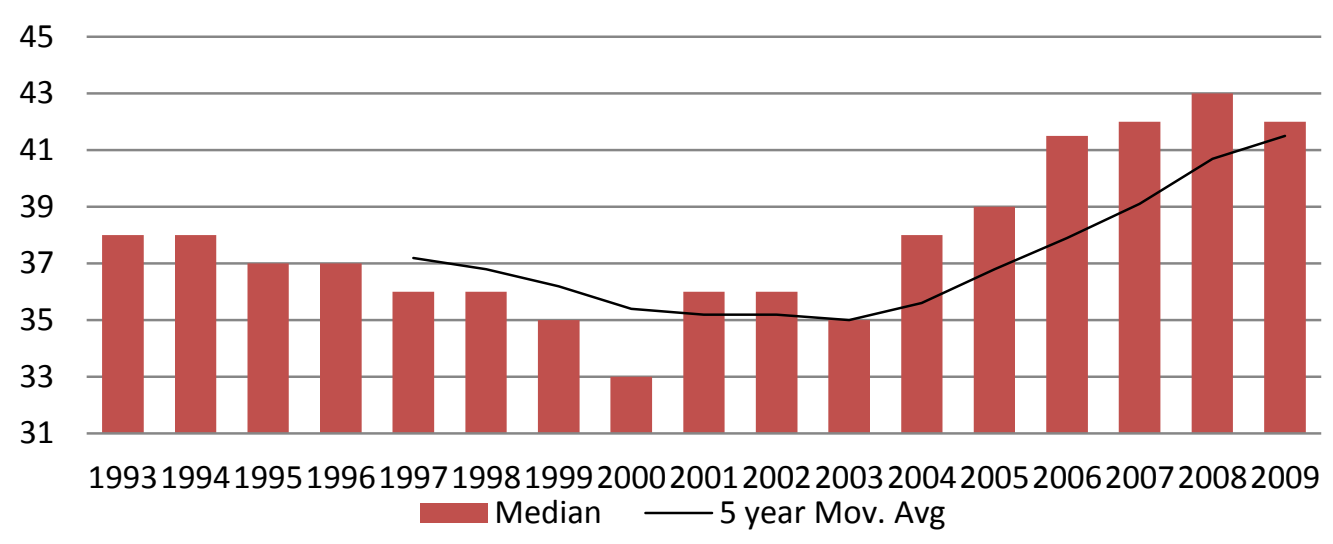

Figure 2: Times-Series Trend of Median Financial Closing Time (in Days) 1993 - 2009

Figure 2 shows the median and five-year moving average of the time lag between fiscal year end and earnings release date. There is a general trend toward decreasing times from the beginning of the sample period until the early 2000s when reporting times started to increase markedly, which can be, in large part, attributed to the new reporting requirements imposed by the Sarbanes-Oxley Act of 2002 and subsequent reporting requirement changes (CFO, 2010). 
The Compustat Execucomp database tracks highly compensated executives (top five through nine) in publicly traded companies. We use this database and manually search for titles containing the key words "information" and "systems", such as "Chief Information Officer" or "Vice President - Chief Information Officer and Controller" or "Senior Vice President - Information Systems" and similar titles. We posit that public firms with senior information executives in the top compensated positions would exhibit enhanced information processing and reporting capabilities.

With regard to cost of equity, the three estimates (GLS, CT and GM) are measured in June of every year. The average of the three measures in excess of the 10-year U.S. Treasury constant maturity rate is the cost of equity capital measure $(C E Q)$ in the literature and the dependent variable in our regression analyses. We obtain analyst forecasts and growth estimates from $\mathrm{I} / \mathrm{B} / \mathrm{E} / \mathrm{S}$ unadjusted historical summary forecasts, book values from the Compustat North America Fundamental Annual Xpressfeed, and stock prices from CRSP. We use the following regression model to test the association between financial closing time $(F C T)$ and cost of equity $(C E Q)$ while controlling for the effect of earnings surprises (ESURP).

$$
C E Q=\beta_{0}+\beta_{1} F C T+\beta_{2} E S U R P+\text { Controls }+\varepsilon_{i, t}
$$

We measure financial closing $F C T$ as the time lag between fiscal year end and earnings announcement date. Similar to prior literature (Brazel and Dang, 2008), earnings surprise ESURP is the difference between actual earnings per share (EPS) and market expectation, scaled by the magnitude of market expectation. We improve this measure by using the $\mathrm{I} / \mathrm{B} / \mathrm{E} / \mathrm{S}$ analyst mean earnings per share forecast as the proxy for market expectation where available. If $\mathrm{I} / \mathrm{B} / \mathrm{E} / \mathrm{S}$ does not have earnings per share information for a particular firm year ${ }^{1}$, then we use prior year's earnings per share from Compustat. The other control variables in the regression model (Eq. 4) follow those in the literature - Indus is the average of industrial implied cost of equity premium based on Fama-French 48 industries. It is included to control for the time-varying industry premium on cost of equity. Size is the market capitalization (fiscal year end share price multiplied by common shares outstanding) of the firm. Disp is the analyst forecast dispersion, measured as the standard deviation of one-year-ahead analyst forecast divided by the mean of forecasts, and the natural $\log$ of dispersion is used following established empirical practice. MTB is the Market-toBook ratio and Mkt_Beta is the market beta in the Capital Asset Pricing Model (Fama and French, 1993) and Lev is the financial leverage ratio (total long-term debt divided by total assets).

The Appendix contains definitions for all the variables used in the paper. Table 1 provides the summary statistics of all the variables used in the study and Table 2 has the regression results based on equation (4). The coefficient on financial closing time is significant and positive, suggesting that increased financial closing time is associated with increased cost of capital. The signs and significance of other control variables are consistent with prior literature. The Market-to-Book (MTB) ratio is a proxy for the investment opportunity sets facing a firm. A higher MTB ratio signals the competitiveness of a firm and therefore a lower required rate of return by investors. In addition to MTB, a firm's beta to the market portfolio indicates its covariance with the overall market and the underlying amount of risk relative to that of the stock market. The negative relationship between dispersion in analyst forecasts and cost of equity is consistent with Miller (1977) in a capital market with short-sale constraints and heterogeneous expectations.

\footnotetext{
${ }^{1}$ To mitigate having zero earnings expectation in the denominator and extreme outlier values of the ESURP measure due to denominators that are in the pennies, we substitute one for the denominator when its absolute value is less than one.
} 
Table 1: Summary Statistics (1993-2010; $\mathbf{n = 2 1 , 8 5 1 )}$

\begin{tabular}{|l|c|c|c|}
\hline \multicolumn{1}{|c|}{ Variable } & Mean & Median & Std Dev. \\
\hline CEQ (in basis points) & 555.05 & 494.35 & 317.59 \\
\hline FCT & 44.83 & 41.00 & 33.88 \\
\hline SIE & 0.06 & 0.00 & 0.24 \\
\hline ESURP & 0.01 & 0.01 & 0.23 \\
\hline INDUS & 0.07 & 0.06 & 0.07 \\
\hline LN_SIZE & 7.04 & 6.91 & 1.65 \\
\hline LN_DISP & 0.08 & 0.03 & 0.18 \\
\hline MTB & 3.74 & 2.13 & 41.68 \\
\hline MKT_BETA & 1.17 & 1.08 & 1.04 \\
\hline LEV & 20.15 & 17.53 & 18.41 \\
\hline LGTA & 7.18 & 6.96 & 1.85 \\
\hline AUDITOP & 2.44 & 1.00 & 1.50 \\
\hline HIGHTECH & 0.29 & 0.00 & 0.45 \\
\hline HIGHLIT & 0.40 & 0.00 & 0.49 \\
\hline FININD & 0.09 & 0.00 & 0.28 \\
\hline HG & 0.31 & 0.00 & 0.46 \\
\hline BIG & 0.93 & 1.00 & 0.26 \\
\hline SEGNUM & 5.36 & 5.00 & 3.33 \\
\hline FOREIGN & 0.37 & 0.00 & 0.48 \\
\hline
\end{tabular}

Table 2: Financial Closing Time and Implied Cost of Capital

Dependent Variable = Implied Cost Of Equity (Ceq), With Fixed Effects Regression Model Based On Fiscal Years 1993-2009

\begin{tabular}{|l|c|c|c|}
\hline & Estimate & Standard Error & p value \\
\hline FCT & 1.33 & 0.06 & $<.0001$ \\
\hline ESURP & -12.64 & 8.32 & 0.1287 \\
\hline INDUS & 204.24 & 27.68 & $<.0001$ \\
\hline LN_SIZE & -40.85 & 1.23 & $<.0001$ \\
\hline LN_DISP & -232.39 & 10.55 & $<.0001$ \\
\hline MKT_BETA & -0.05 & 0.05 & 0.267 \\
\hline LEV & 14.22 & 1.86 & $<.0001$ \\
\hline R-square=0.21 & 2.78 & 0.10 & $<.0001$ \\
\hline
\end{tabular}

The positive sign on earnings surprises (ESURP) is consistent with existing literature (Mikhail et al, 2004) since the measurement of implied cost of equity is an ex-ante market expectation of future earnings over a relative long period of time into the future. Firms with current large earnings surprises may be considered as lacking the needed earnings persistence which therefore suggests increased risks for investors. In sum, the results in Table 3 seem to suggest that delayed financial closing time signals information risk to the market participants. As a result, external investors adjust their risk assessments, demand higher risk premiums and a higher cost of capital incurred for the firm.

In the theoretical development section, we have posited that senior IS executives help reduce financial closing times and improve the information environment. To test this empirically, we use the following regression model and control variables based on the literature.

$$
\begin{aligned}
F C T= & \delta_{\text {year }}+\delta_{1} S I E+\delta_{2} E S U R P+\delta_{3} L G T A+\delta_{4} A U D O P N+\delta_{5} L E V+\delta_{6} H I T E C H+\delta_{7} H I L I T+\delta_{8} F I N \\
& +\delta_{9} H I G W+\delta_{10} B I G 4+\delta_{11} S E G N U M+\delta_{12} F O R E I G N+\varepsilon
\end{aligned}
$$

We use SIE as an indicator variable to equal one once a firm had a senior executive with title in the information systems functions and among the most compensated company executives. We further control for known significant determinants of reporting lag identified in literature (Brazel and Dang, 2008; Krishnan and Yang, 2009). LGTA is the natural $\log$ of total assets. AUDOPN is whether the auditor opinion is qualified. Krishnan and Yang (2009) show that firms in High Tech (HITECH), Financial (FIN), and High Growth (HIGW) industries tend to have shorter reporting lags. SEGNUM measures the number of reporting segments and BIG4 is an indicator variable on 
whether firms' independent auditors are E\&Y, Deloitte, KPMG, PWC (and Arthur Andersen prior to 2003). We also include an additional control variable - FOREIGN - to represent whether a company has income from foreign sources. Lee et al (2008) argue that companies with more significant multinational operations tend to exhibit shorter reporting lags compared to those firms that are mostly or exclusively domestic, and the omission of a foreignincome variable could thus potentially confound our results. To control for the yearly effects of financial closing time, as shown in Figure 1, we run fixed effects model by year for equation (5).

Table 3: Financial Closing Time and Senior Information Executives

Dependent Variable $=$ Financial Closing Time (FCT), With Fixed Effects Regression Model Based On Fiscal Years 1993-2009

\begin{tabular}{|l|c|c|c|}
\hline \multicolumn{1}{|c|}{ SIE } & Estimate & Standard Error & P value \\
\hline ESURP & -4.138 & 0.915 & $<.0001$ \\
\hline LGTA & -2.778 & 0.961 & 0.0038 \\
\hline AUDITOP & -2.114 & 0.152 & $<.0001$ \\
\hline LEV & -0.117 & 0.168 & 0.484 \\
\hline HITECH & 0.043 & 0.013 & 0.0013 \\
\hline HILIT & -3.339 & 0.732 & $<.0001$ \\
\hline FIN & -6.299 & 0.720 & $<.0001$ \\
\hline HIGW & -3.693 & 0.863 & $<.0001$ \\
\hline BIG4 & 0.483 & 0.512 & 0.3451 \\
\hline SEGNUM & -9.539 & 0.881 & $<.0001$ \\
\hline FOREIGN & 1.768 & 0.077 & $<.0001$ \\
\hline R-square=0.07 & -8.630 & 0.519 & $<.0001$ \\
\hline
\end{tabular}

The results in Table 3 shows that, on average, having employed senior executives in the IS functions is associated with a reduction in the financial closing time by more than four days. In addition, the effects of the control variables are significant and consistent with prior literature. This highlights the importance of the role of IS executives in reducing closing time, which is distinctive from other factors that influence reporting lag, such as negative or positive earnings surprises, capital structure, industry, and auditor effects.

Furthermore, having senior IS executives may contribute in ways other than reducing reporting lag. For this reason, we test whether having senior IS people in top management improves the overall information capabilities of a firm, satisfying investors' information demand and therefore lowering firms' cost of capital.

$$
C E Q=\beta_{0}+\beta_{1} F C T+\beta_{2} E S U R P+\beta_{3} S I E+\text { Controls }+\varepsilon
$$

Table 4: Senior IS Executive and Cost of Equity Dependent Variable $=$ Implied Cost of Equity (in Basis Points). Fixed Effects Model

\begin{tabular}{|l|c|c|c|}
\hline \multicolumn{1}{|c|}{ FCT } & Estimate & Standard Error & p Value \\
\hline SIE & 1.06 & 0.06 & $<.0001$ \\
\hline ESURP & -23.34 & 7.73 & 0.0025 \\
\hline INDUS & -9.43 & 8.12 & 0.2457 \\
\hline LN_SIZE & 145.30 & 27.11 & $<.0001$ \\
\hline LN_DISP & -49.54 & 1.31 & $<.0001$ \\
\hline MTB & -226.50 & 10.34 & $<.0001$ \\
\hline MKT_BETA & -0.03 & 0.04 & 0.467 \\
\hline LEV & 15.22 & 1.82 & $<.0001$ \\
\hline HITECH & 2.48 & 0.11 & $<.0001$ \\
\hline HILIT & 1.95 & 6.19 & 0.7527 \\
\hline FIN & -60.60 & 6.02 & $<.0001$ \\
\hline HIGW & 136.49 & 7.03 & $<.0001$ \\
\hline BIG4 & -12.01 & 4.31 & 0.0053 \\
\hline SEGNUM & -10.04 & 7.41 & 0.1755 \\
\hline FOREIGN & 12.07 & 0.63 & $<.0001$ \\
\hline R-square $=0.25$ & -15.39 & 4.45 & 0.0005 \\
\hline
\end{tabular}


In Table 4, we run the regression model using equation (6) and show that having senior information executives is associated with an overall lower implied cost of equity. This association is statistically and economically significant. In addition to delivering business value through better financial reporting capabilities, senior information executives integrate technology in various business processes. This can lower operating cost and improve financial performance, leading to an overall reduction in firms' cost of equity capital.

\section{CONCLUSION}

We examine the relation between financial closing time and implied cost of equity capital, and whether senior IS executives may help reduce financial closing time and thus mitigate the effect of information asymmetry on firm valuation. Specifically, we show that each day of delay in the release of earnings information is associated with an increased cost of equity capital. We then find an association between senior IS executives and shorter financial closing time. This association is statistically significant and economically meaningful. Firms with senior IS executives can reduce their financial closing time by more than four days. This result is robust after controlling for other variables affecting reporting lags that have been established in the literature, including industry effect, reporting complexity, and auditors.

Based on the upper echelon theory and the resource-based view, we contribute by pointing out the role of senior information executives on timely financial reporting and the rippling effect on firms' cost of equity capital. As an empirical work, this study is limited by the depth of information that is observable from publicly available data. Future in-depth case studies examining the effects of senior information executives on firm IT capabilities and accounting processes are surely needed. Such work would also include survey evidence on how senior information executives help integrate existing reporting process and/or implementing new systems for enterprise resource planning, thereby creating strategic advantages for the company.

\section{AUTHOR INFORMATION}

Mingjun Zhou is an Assistant Professor in the School of Accountancy and Management Information Systems at DePaul University. He earned his Ph.D. from Texas Tech University. His research interests focus on the impact of information systems and executives on firm financial measures. His articles appeared in Accounting and Taxation and Journal of Accounting, Ethics and Public Policy. E-mail: mzhou4@depaul.edu (Corresponding author)

Miguel I. Aguirre-Urreta is an Assistant Professor in the School of Accountancy and Management Information Systems, Richard H. Driehaus College of Business, at DePaul University in Chicago, IL USA. His work has been published or is forthcoming in MIS Quarterly, The DATA BASE for Advances in Information Systems, the Journal of Organizational and End User Computing, Research Synthesis Methods, Human Technology, and Communications of the Association for Information Systems. His research interests are in the areas of individual performance with the use of technology, technology acceptance and diffusion, systems analysis and design, and research methods.

\section{REFERENCES}

1. Barry, C. and Brown, S. (1985). Differential Information and Security Market Equilibrium. Journal of Financial and Quantitative Analysis, 20, 407-422.

2. Barry, C. and Brown, S. (1986). Limited Information as a Source of Risk. The Journal of Portfolio Management, 12, 66-72.

3. Brazel, J. and Dang, L. (2008).The Effect of ERP System Implementations on the Management of Earnings and Earnings Release Dates. Journal of Information Systems, 22 (2), 1-21.

4. CFO Research Services. (2010). Accelerating the Financial Close: CFO's Insights into the Benefits of a High-Quality Close. CFO Publishing, LLC.

5. Chambers, A., and Penman, S. (1984). Timeliness of Reporting and the Stock Price Reaction to Earnings Announcements. Journal of Accounting Research, 22 (1), 21-47.

6. Claus,J., and Thomas, J. (2001). Equity Premier as Low as Three Percent? Empirical Evidence from Analysts' Earnings Forecasts for Domestic and International Stock Markets. Journal of Finance, 56, 16291666. 
7. DeFond, M., Hung, M. and Relevant, R. (2007). Investor Protection and the Information Content of Annual Earnings Announcements: International Evidence. Journal of Accounting and Economics, 43 (1), $37-67$.

8. Diamond, D. (1985).Optimal Release of Information by Firms. Journal of Finance, 40 (4), $1071-1094$.

9. $\quad$ Ein-Dor, P., and Segev, E. A Paradigm for Management Information Systems. New York: Praeger, 1981.

10. Elton, E. (1999). Expected Return, Realized Return, and Asset Pricing Tests. Journal of Finance, 54, 11991220.

11. Fama, E. and French, K. (1993). Common Risk Factors in the Returns of Stocks and Bonds. Journal of Financial Economics, 33, 3-56.

12. Fama, E. and French, K. (1997). Industry Cost of Equity. Journal of Financial Economics, 43, $153-93$.

13. Gebhardt, L., Lee, C. and Swaminathan, B. (2001).Toward an Implied Cost of Equity Capital. Journal of Accounting Research, 39, 135-176.

14. Givoly, D., and Palmon, D. (1982). Timeliness of Annual Earnings Announcements: Some Empirical Evidence. The Accounting Review, 57 (3), 486-508.

15. Gode, D., and Mohanram, P. (2003). Inferring Cost of Equity Capital using the Ohlson-Juttner Model. Review of Accounting Studies, 8, 399-431.

16. Grossman, S. (1981). The Informational Role of Warranties and Private Disclosure About Product Quality. The Journal of Law and Economics, 24 (3), 461-489.

17. Grover, V., Jeong, S., Kettinger, W. and Lee, C. (1993). The Chief Information Officer: A Study of Managerial Roles. Journal of Management Information Systems, 10 (2), 107-130.

18. Hambrick DC and Mason PA (1984) Upper Echelons: the Organization as a Reflection of its Top Managers. Academy of Management Review 9 (2).

19. Haw, I., Qi, D. and Wu, W. (2000). Timeliness of Annual Report Releases and Market Reaction to Earnings Announcements in an Emerging Capital Market: The Case of China. Journal of International Financial Management and Accounting, 11 (2), 108-131.

20. Healy, P. and Palepu, K. (2001). Information Asymmetry, Corporate Disclosure, and the Capital Markets: A Review of the Empirical Disclosure Literature. Journal of Accounting and Economics, 31 (1-3), 405-440.

21. Kasznik, R. and Lev, B. (1995). To Warn or Not to Warn: Management Disclosures in the Face of Earning Surprises. The Accounting Review, 70 (1), 113-134.

22. Khallaf, A. and Skantz, T. (2007). The Effects of Information Technology Expertise on the Market Value of a Firm. Journal of Information Systems, 21 (7), 83-105.

23. Krishnan, J., and J. Yang. 2009. Recent Trends in Audit Report and Earnings Announcement Lags. Accounting Horizons, 13 (3), 265-288.

24. Li, S. and Pinsker, R. (2005). Modeling RBRT Adoption and its Effects on Cost of Capital. International Journal of Accounting Information Systems, 6, 196-215.

25. Leventis, S., and Weetman, P. (2004). Timeliness of Financial Reporting: Applicability of Disclosure Theories in an Emerging Capital Market. Accounting and Business Research, 34 (1), 43-56.

26. Mata FJ, Fuerst WL, Barney JB. (1995) Information Technology and Sustained Competitive Advantage: A Resource-Based Analysis. MIS Quarterly 19 (4): 487-505.

27. Miller, E. (1977). Risk, Uncertainty, and Divergence of Opinion. Journal of Finance, 32, 1151-68.

28. Mikhail, M., Walther, B. and Willis, R. (2004). Earnings Surprises and Cost of Capital. Working Paper. Duke University and Northwestern University.

29. Merton, R. (1987). A Simple Model of Capital Market Equilibrium with Incomplete Information. The Journal of Finance, 42, 483-510.

30. Myers, S. and Majluf, N. (1984). Corporate Financing and Investment Decisions When Firms have Information that Investors do not have. Journal of Financial Economics, 13, 187-221.

31. Raghunathan, B. and Raghunathan, T. (1989). Relationship of the Rank of Information Systems Executive to the Organizational Role and Planning Dimension of Information Systems. Journal of Management Information Systems, 6 (1), 111-25.

32. Rockart, J., Ball, L. and Buleen, C. (1982). Future Role of the Information Systems Executive. MIS Quarterly, 6, 1-15.

33. Verrechia, R. (1990). Endogenous Proprietary Costs Through Firm Interdependence. Journal of Accounting and Economics, 12 (1-3), 245-250.

34. Wang, L. and Alam, P. (2007). Information Technology Capability: Firm Valuation, Earnings Uncertainty, and Forecast Accuracy. Journal of Information Systems, 21 (2), 27-48. 


\section{APPENDIX}

\section{Variable Definitions}

$C E Q=$ implied cost of equity premium in basis points

$F C T$ = financial closing time and is measured as the time lag (in days) between fiscal year end and earnings announcement date

SIE $=1$ when firms having had highly compensated senior executive in the information systems function, zero otherwise.

$E S U R P=$ difference between actual earnings and market expectation of earnings, scaled by the market expectation

Indus = average industry implied cost of equity premium by on Fama-French 48 industries

$L N \_S I Z E=$ natural log of firms size in millions

$L N \_D I S P=$ natural log of the dispersion of one-year ahead analyst earnings forecast, measured as the standard deviation of forecasts dividend by mean forecast.

$M T B=$ Market-to-Book ratio

$L t g=$ Consensus long-term growth rate provided by $\mathrm{I} / \mathrm{B} / \mathrm{E} / \mathrm{S}$

Mkt_Beta $=$ firm's market beta relative to the market portfolio returns provided by Kenneth French (Fama and French, 1993)

$L G T A=$ natural $\log$ of total assets

$S E G N U M=$ the number of business segments

FOREIGN $=1$ if firm has income from foreign sources and 0 otherwise

$A U D O P N=1$ if the auditor opinion is qualified and 0 otherwise

$H I G W=1$ if firm is in a high growth industry and 0 otherwise. High-growth industries are represented by the following SIC codes: $35,45,48,49,52,57,73,78$, and 80.

HILIT $=1$ if firm is in a highly litigious industry during filing date $\mathrm{t}$, and 0 otherwise. High-litigation industries are represented by the following SIC codes: $28,35,36,38,60,67$ and 73 .

$H I T E C H=1$ if firm is in a high-tech industry during filing date t, and 0 otherwise. High-tech industries are represented by the following SIC codes: 283, 284, 357, 366, 367, 371, 382, 384, and 737.

$F I N=1$ if firm is in a financial industry during filing date $\mathrm{t}$, and 0 otherwise. Financial industries are represented by the following SIC codes: 60-67 
NOTES 